\title{
PERANCANGAN SISTEM INFORMASI PENJUALAN PERLENGKAPAN PERTANIAN PADA TOKO DIANA PHON JAKARTA
}

\author{
Zaqia Ihtiarqi Rahayu', Muhammad Soleh Ritonga² \\ ${ }^{1,2}$ Universitas Indraprasta PGRI \\ Jalan Raya Tengah No 80, Kelurahan Gedong, Pasar Rebo, Jakarta Timur \\ 1zihtiarqir@gmail.com, ${ }^{2}$ soleh_0502@yahoo.com
}

\begin{abstract}
ABSTRAK
Sistem Informasi Penjualan ialah sebuah sistem yang bertujuan untuk melakukan proses pengolahan data penjualan. Toko Diana Phon masih belum terdapat pengelolaan data transaksi penjualan secara cepat dan akurat. Solusi untuk mengatasi masalah pada Toko Diana Phon yaitu dengan merancang sistem transaksi penjualan produk pertanian yang meliputi beberapa proses transaksi antara lain proses mengolah data barang, customer, supplier, barang masuk, dan faktur penjualan. Oleh karena itu, peneliti membangun suatu sistem untuk pengelolaan data berbasis komputer dengan tujuan untuk mempermudah administrasi dalam memberikan laporan-laporan penjualan untuk meminimalisir kesalahan serta memberikan data dengan akurat serta cepat dan meningkatkan kinerja karyawan didalam perusahaan.
\end{abstract}

Kata Kunci: Perancangan, Sistem Informasi Penjualan

\begin{abstract}
Sales Information System is a system that aims to process sales data processing. Diana Phon store still does not have a fast and accurate management of sales transaction data. Solution to problem at the Diana Phon Store is to design a transaction system for selling agricultural products which includes several transaction processes, including the process of processing data on goods, customers, suppliers, incoming goods, and sales invoices. Therefore, the researchers built a system for computer-based data management with the aim of facilitating administration in providing sales reports to minimize errors and provide data accurately and quickly and improve employee performance within the company.

Keywords: Design, Sales Information System
\end{abstract}

\section{PENDAHULUAN}

Sistem informasi penjualan ialah suatu sistem yang berperan untuk mengolah data-data terkait dengan aktifitas penjualan baik dari transaksi pembelian hingga transaksi penjualan digunakan untuk menunjang aktifitas penjualan tersebut(Furqon 2013).

Pembuatan ataupun pengaturan sistem penjualan mempengaruhi pada tingkatan penerimaan pemasukan industri. Oleh sebab itu industri wajib benar-benar mengawasi serta mengatur aktivitas penjualan dengan mempraktekkan sesuatu sistem yang mencukupi, sehingga sasaran penjualan bisa dicapai. Perkembangan teknologi saat ini amat sangat pesat, salah satunya perkembangan teknologi komputer.

Komputer sendiri merupakan fitur elektronik yang dirancang untuk menerima inputan data serta diproses menjadi sesuatu sistem informasi menggunakan program komputer dan ditaruh di memori. Pemanfaatan teknologi data tentunya jadi pemecahan yang pas buat menanggulangi kasus yang terdapat pada Toko Diana Phon, sebab dengan suatu sistem terkomputerisasi proses pengelolaan informasi transaksi produk pertanian jadi jauh lebih baik.

Toko Diana Phon menjual produk-produk penunjang pertanian yaitu pestisida, pupuk, benih tanaman, pot, dan alat-alat pertanian. Selama ini sistem penjualan Toko Diana Phon masih belum terdapat pengolahan data dan penjualan secara cepat, pencatatan penjualan masih ditulis dengan manual di buku, pada pembayaran faktur masih ditulis dengan kertas, laporan-laporan setiap bulannya seperti stok barang dan transaksi menggunakan aplikasi Ms.Access. Perihal ini pemilik Toko Diana Phon merasa kesusahan buat menganalisa laporan-laporan penjualan yang masih dalam wujud rekap penjualan. 
Berdasarkan kasus tersebut, sehingga Toko Diana Phon memerlukan suatu sistem data penjualan yang dapat menciptakan laporanlaporan penjualan barang tiap harinya atau bulanan, laporan stok barang, laporan data barang, serta laporan pembelian barang masuk buat menolong proses pengolahan informasi penjualan serta menanggulangi masalahmasalah yang terdapat pada Toko Diana Phon.

Dengan ini penulis membuat Perancangan Sistem Informasi Transaksi Penjualan Perlengkapan Pertanian Pada Toko Diana Phon Jakarta. Perancangan merupakan suatu proses untuk mendefinisikan suatu yang akan dikerjakan dengan menggunakan teknik yang bermacam-macam dan di dalamnya melibatkan deskripsi mengenai arsitektur dan detail komponen serta keterbatasan yang akan dialami dalam proses pengerjaannya(Soetam, 2011).

$\begin{array}{lrr}\begin{array}{l}\text { Sedangkan } \\ \text { kumpulan/group }\end{array} & \text { sistem } & \text { merupakan } \\ \text { dari } & \text { sub }\end{array}$ sistem/bagian/komponen apapun baik fisik ataupun non fisik yang saling berhubungan satu sama lain serta bekerja sama secara harmonis untuk menggapai satu tujuan tertentu(Susanto, 2013). Dan Informasi merupakan hasil pengolahan data, tetapi tidak semua hasil pengolahan data yang bukan hasil pengolahan tersebut dapat disebut informasi, hasil pengolahan data tidak memberikan makna, arti atau penjelasan serta tidak berguna bagi siapapun atau penerima informasi bukanlah merupakan informasi bagi orang tersebut(Darmawan, K.N. Fauzi, 2013).

Kemudian, transaksi merupakan peristiwa terjadinya aktivitas bisnis yang dilakukan oleh suatu perusahaan(Susanto, 2013), sehingga diharapkan perancangan sistem informasi transaksi ini dapat menolong pemilik Toko Diana Phon untuk meningkatkan pelayanan kepada customer. Serta juga menciptakan laporan-laporan yang dapat digunakan untuk menganalisa informasi penjualan pada periode sebelumnya sebagai dasar untuk pengambilan keputusan.

Bahasa perograman yang dipakai dalam perancangan ini ialah bahasa Java. Java ialah bahasa berorientasi objek yang digunakan untuk mengembangkan aplikasi mandiri, aplikasi berbasis internet, aplikasi untuk fitur pintar yang bisa berkomunikasi lewat internet ataupun jaringan komunikasi. Teknologi java memungkinkan perangkat audio stereo rumah untuk terhubung ke jaringan komputer. Java tidak lagi hanya untuk membuat cmdlet. Halaman web, tetapi Java telah menjadi bahasa pengembang aplikasi web komersial yang hebat.(Haryanto, 2011).

Netbeans ialah salah satu IDE yang dikembangkan dengan pengembang bahasa pemrograman java, netbeans memiliki pemrograman data yang di dalamnya menyediakan pembangunan pemrograman GUI, text editor, compiler, serta interpreter. Netbeans ialah perangkat lunak open source yang dapat digunakan untuk tujuan komersial maupun non komersial secara gratis dengan dukungan Sun Microsystem(Westriningsih, 2012).Aplikasi pengembang yang dipakai adalah Xampp. XAMPP ialah paket software web yang lengkap, dapat anda gunakan untuk belajar pemrograman web, khususnya PHP dan MySQL(Nugroho, 2013).

Pada perancangan ini data-data penjualan akan tersimpan dengan baik dalam suatu database ataupun basis data yang memiliki mekanisme pengelolaan data dalam jumlah yang besar secara terstruktur. Database mempermudah program untuk mengambil serta menyimpan data. Jika data yang diolah banyak serta memerlukan penanganan khusus, jangan menggunakan file untuk menyimpan data. Tetapi, gunakan database(Andi Taufik, 2013). Keberadaan database untuk memenuhi kebutuhan aplikasi. Aplikasi adalah unit perangkat lunak yang dibuat untuk memenuhi kebutuhan berbagai aktivitas (Astuti, 2013).

Tujuan penelitian ini ialah merancang sistem informasi transaksi penjualan produk pertanian yang meliputi beberapa proses transaksi antara lain proses mengolah data barang, pelanggan, supplier, barang masuk, dan faktur penjualan. Serta merancang sistem informasi pembuatan laporan-laporan transaksi produk pertanian antara lain laporan data barang, stok barang, penjualan, serta pembelian. 


\section{METODE PENELITIAN}

Penelitian ini dilakukan di Toko Diana Phon yang beralamat Jalan Raya Cilangkap Rt/001 Rw/05 No.15 Telp:(021)8454843, Cilangkap, Cipayung Jakarta Timur. Pelaksanaan penelitian ini dilakukan dalam waktu lima bulan, mulai bulan Maret 2021 sampai dengan Juli 2021.

Rancangan kegiatan tersebut dimulai pada bulan maret 2021 dengan cara mengadakan kunjungan langsung ke lapangan untuk mencatat hal-hal penting dan sesuai dengan masalah, lalu melakukan wawancara tatap muka dengan karyawan Toko Diana Phon.

Wawancara merupakan pertemuan yang dilakukan oleh dua orang untuk bertukar informasi ataupun suatu ide dengan metode tanya jawab, sehingga dapat dikerucutkan menjadi suatu kesimpulan ataupun arti dalam topik tertentu(Sugiyono, 2015). Dengan mengumpulkan data serta informasi dari berbagai kutipan yang ada dalam buku-buku referensi, jurnal, peraturan perundangundangan, serta hasil laporan dan bahan lainnya yang berkaitan dengan penelitian ini.

Metode pengumpulan data juga dilakukan dengan mengumpulkan berbagai data dari narasumber ataupun ahli-ahli di bidang tersebut serta riset literatur yang dapat digunakan sebagai bahan untuk perancangan produk, diharapkan dapat menanggulangi masalah yang ada. Riset ditujukan untuk menciptakan konsep-konsep teori yang memperkuat suatu produk, khususnya mengenai transaksi, misalnya produk berupa model, program, sistem, pendekatan sistem dan lain sebagainya. Riset literatur juga diperlukan untuk mengetahui langkahlangkah paling tepat untuk pengembangan produk(Sugiyono, 2015).

Sedangkan metode penelitian ini menggunakan Research and Development (R\&D). Research and Development (R\&D) merupakan tata cara penelitian yang digunakan untuk penciptakan produk tertentu, serta menguji keefektifan produk tersebut(Sugiyono, 2015).

Metode penelitian lainnya yang digunakan peneliti adalah pengembangan sistem yang sesuai dengan kebutuhan menggunakan model air terjun (waterfall). Waterfall merupakan tata cara yang menganjurkan suatu pendekatan yang sistematis dan sekuensial melalui tahapan-tahapan yang ada pada Systems Development Life Cycle (SDLC) untuk membangun sebuah perangkat lunak(Rosa, A. Shalahuddin 2015). Penulis menggunakan model waterfall karena metode ini menekankan pada urutan dalam proses pengembangan perangkat lunak dan merupakan metode yang cocok untuk membuat perangkat lunak yang tidak terlalu besar dan memiliki personel yang terbatas.(Rosa, A. Shalahuddin, 2015).

\section{HASIL DAN PEMBAHASAN}

Berdasarkan hasil penelitian kasus sebelumnya, peneliti menaruh analisa konflik berdasarkan sistem pengelolaan data diantaranya:

1. Sistem penyimpanan serta pengelolaan data masih belum terkomputerisasi dan belum memakai sistem database sebagai akibatnya proses penyimpanan serta pengelolaan data menjadi kurang efektif.

2. Proses transaksi barang, saat ini belum terintegrasi dengan baik sebagai akibatnya mengakibatkan lambatnya pekerjaan pengelolaan data.

3. Proses pada pembuatan laporan-laporan saat ini belum terintegrasi dengan baik juga akibatnya mengakibatkan lambatnya pekerjaan pada pembuatan laporan data.

Dari kasus diatas penyelesaiannya dengan merancang dan mengembangkan sistem yang terkomputerisasi dan terintegrasi ke pada sistem database yang bisa memudahkan dalam mengelola dan menyimpan data. Sistem yang diharapkan minimal memiliki fungsi:

1. Pendataan barang

2. Pendataan customer

3. Pendataan supplier

4. Pengelolaan transaksi penjualan

5. Pengelolaan transaksi pembelian

6. Serta pembuatan laporan data barang, data stok barang, data penjualan barang, dan data pembelian barang.

\section{Diagram Konteks Sistem}

Berikut ialah gambaran sistem pada sistem penjualan di Toko Diana Phon dalam bentuk diagram konteks. 


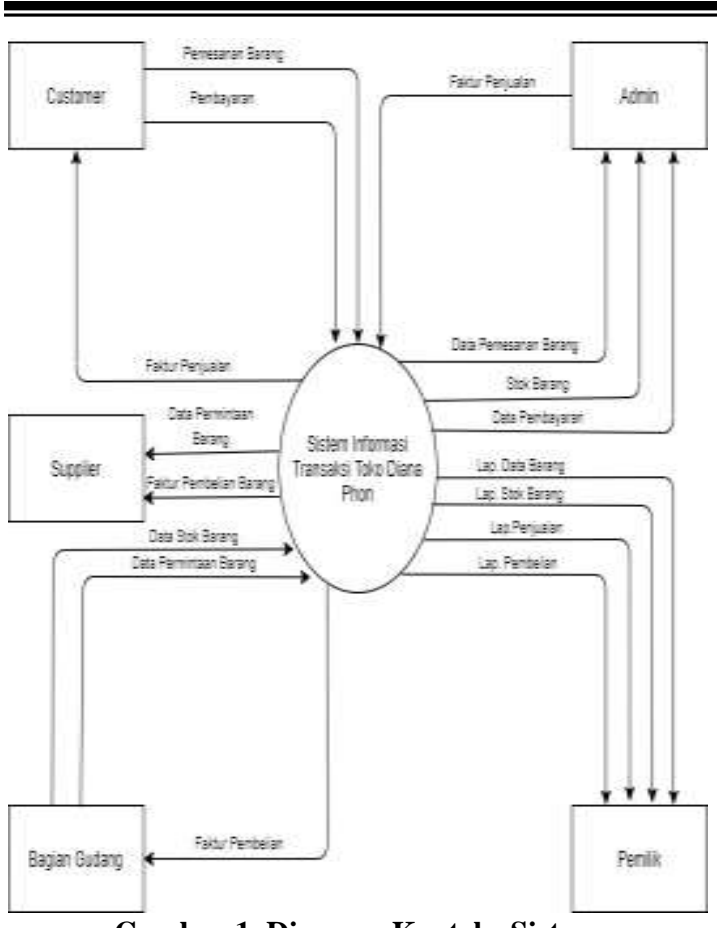

Gambar 1. Diagram Konteks Sistem

\section{Diagram Nol Sistem}

Diagram nol merupakan gambaran proses sistem berjalan pada sistem penjualan yang menggambarkan tahap-tahap proses dari diagram konteks, yaitu:

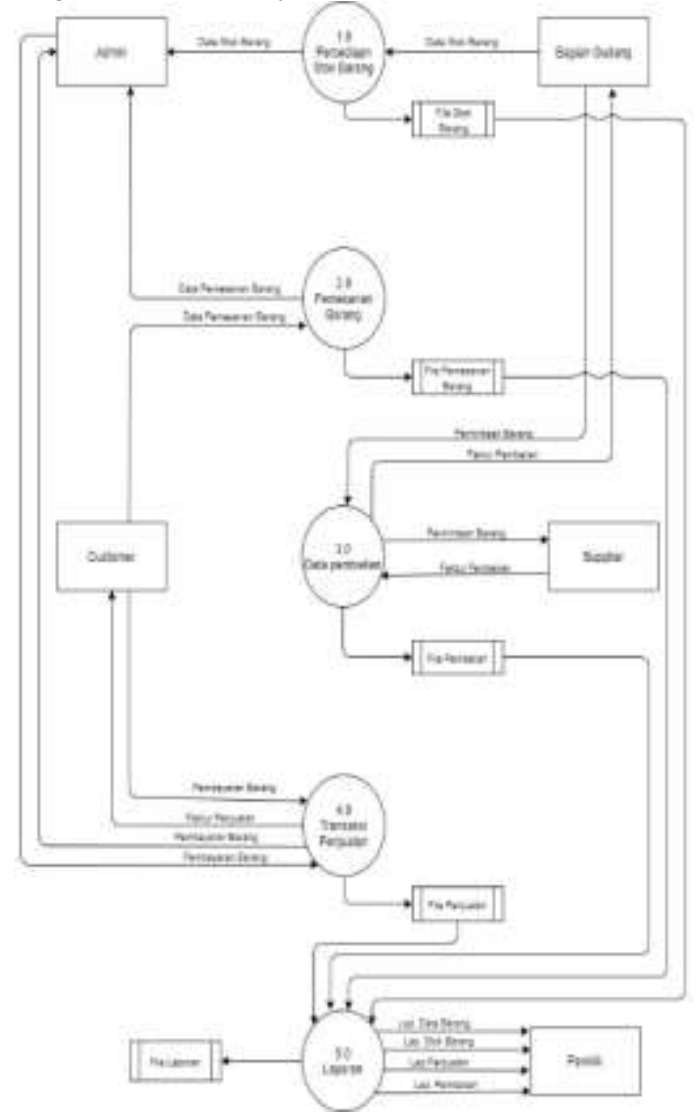

Gambar 2. Diagram Nol Sistem

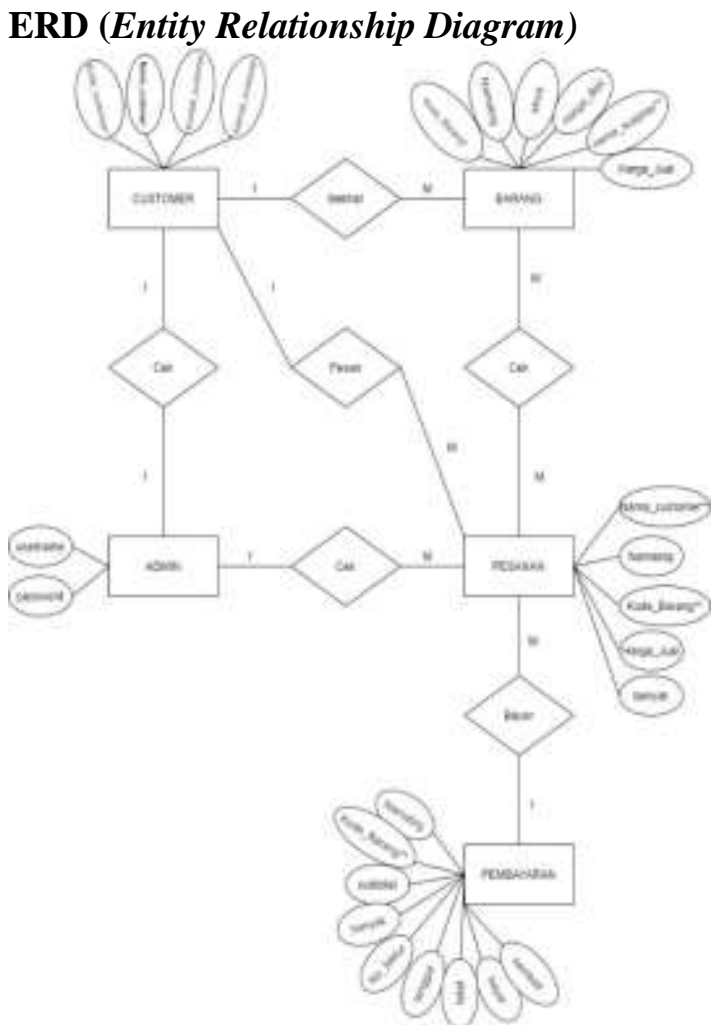

Gambar 3. ERD

\section{Tampilan Layar}

Berikut ini adalah tampilan layar yang telah diimplementasikan serta pengujian pada sistem yang sudah dirancang serta dibuat dengan menggunakan bahasa pemrograman JAVA serta sistem database-nya ialah MySQL.

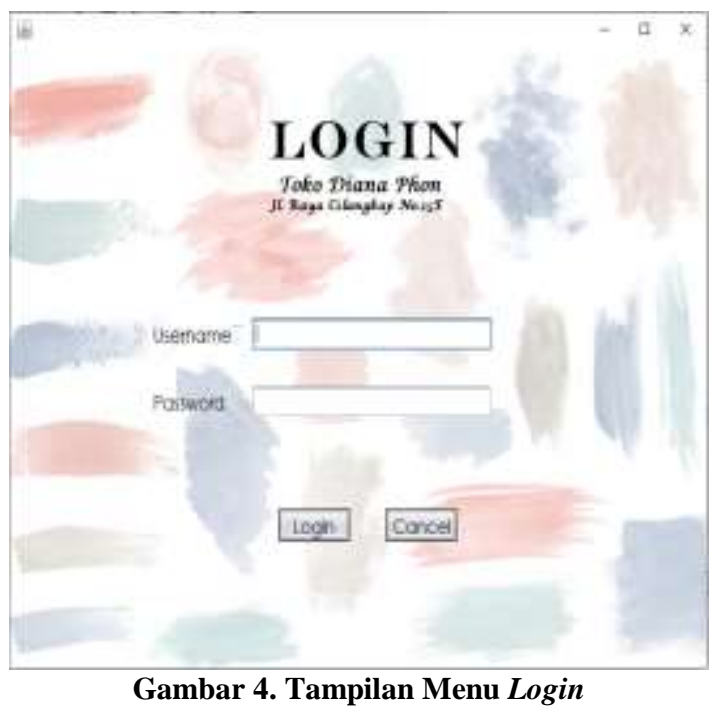

Tampilan menu login dari sistem yang dirancang diatas adalah untuk melakukan akses sebelum masuk ke dalam menu utama serta menu-menu yang terdapat pada sistem. 


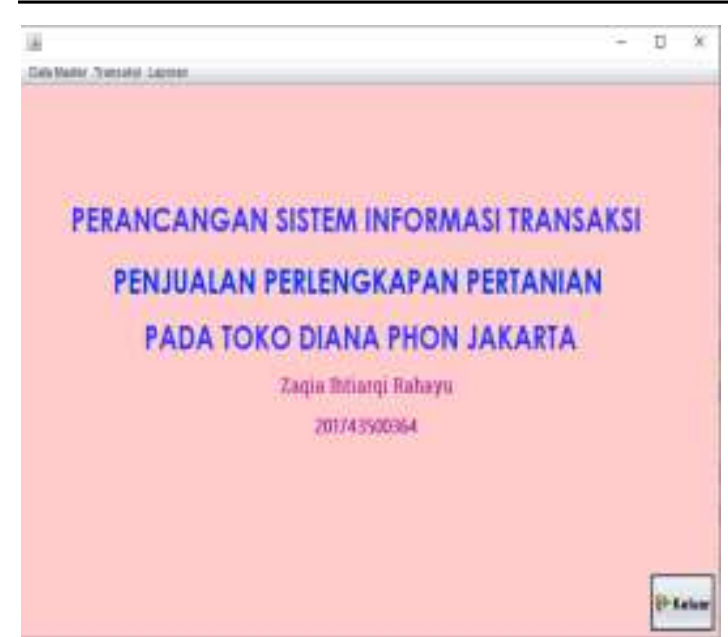

Gambar 5. Tampilan Menu Utama

Tampilan menu utama dari sistem yang dirancang diatas adalah untuk memilih menu sesuai dengan kegiatan proses pekerjaan yang dibutuhkan. Didalamnya ada beberapa sub menu yang dirancang seperti menu data master, menu transaksi, dan menu laporan.

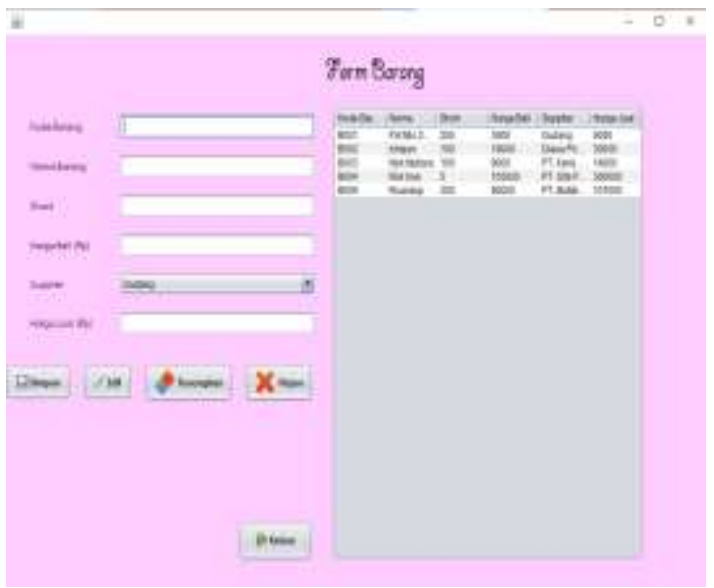

Gambar 6. Tampilan Menu Form Data Barang

Tampilan menu form data barang diatas mempunyai fungsi untuk melakukan adanya proses penginputan data barang.

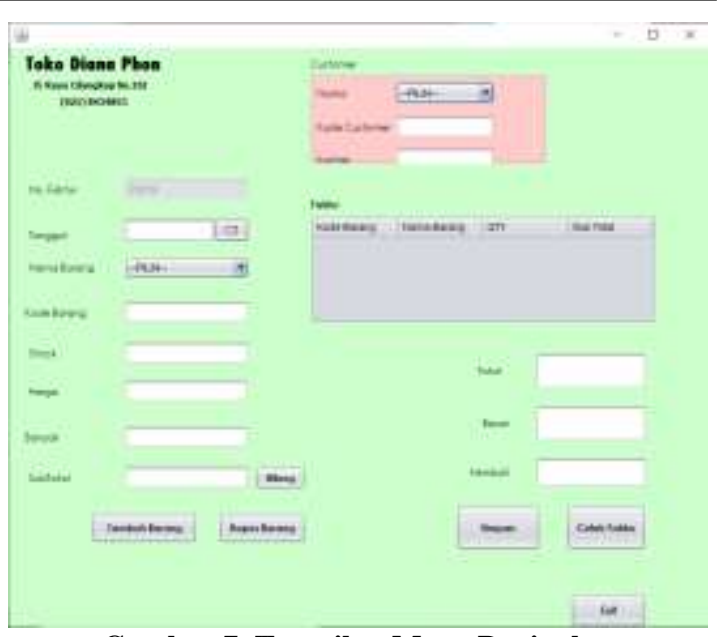

Gambar 7. Tampilan Menu Penjualan

Menu penjualan diatas yang berfungsi mengelola transaksi penjualan suatu barang.

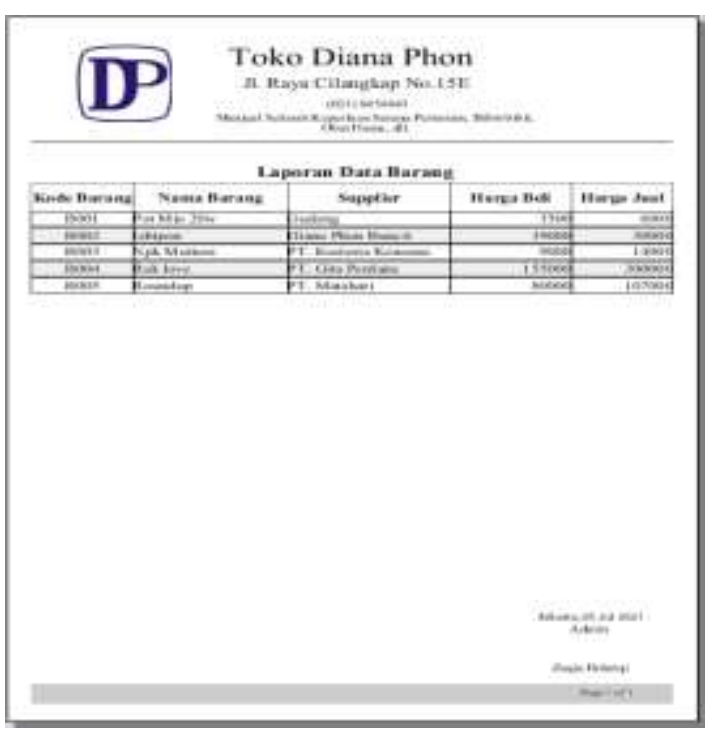

Gambar 8. Tampilan Laporan Data Barang

Tampilan diatas merupakan tampilan Form barang dari menu data master yang akan dijadikan laporan. 


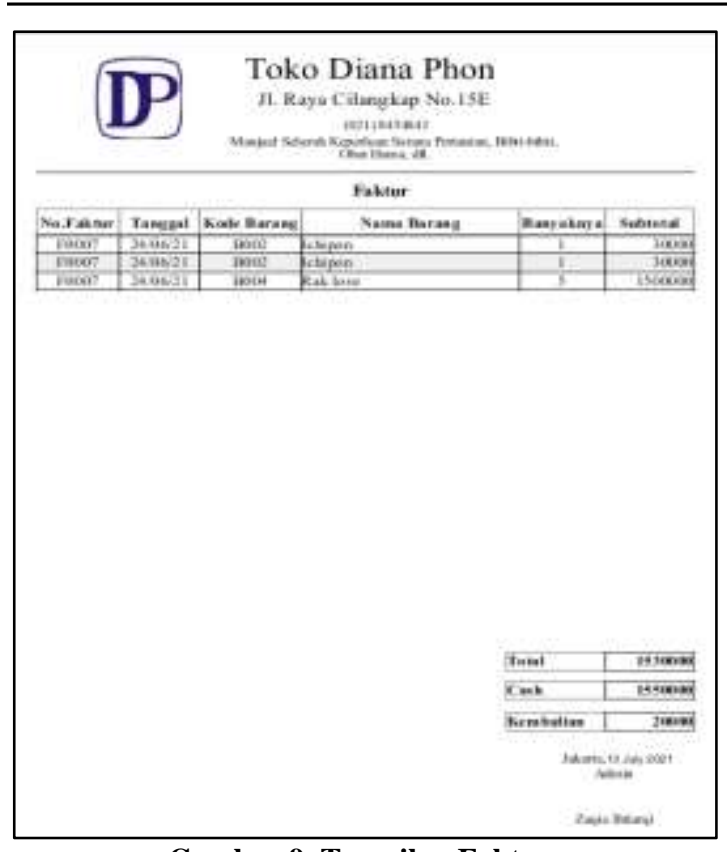

Gambar 9. Tampilan Faktur

Tampilan diatas merupakan tampilan Faktur penjualan dari menu data transaksi penjualan untuk tanda bukti pembelian Customer.

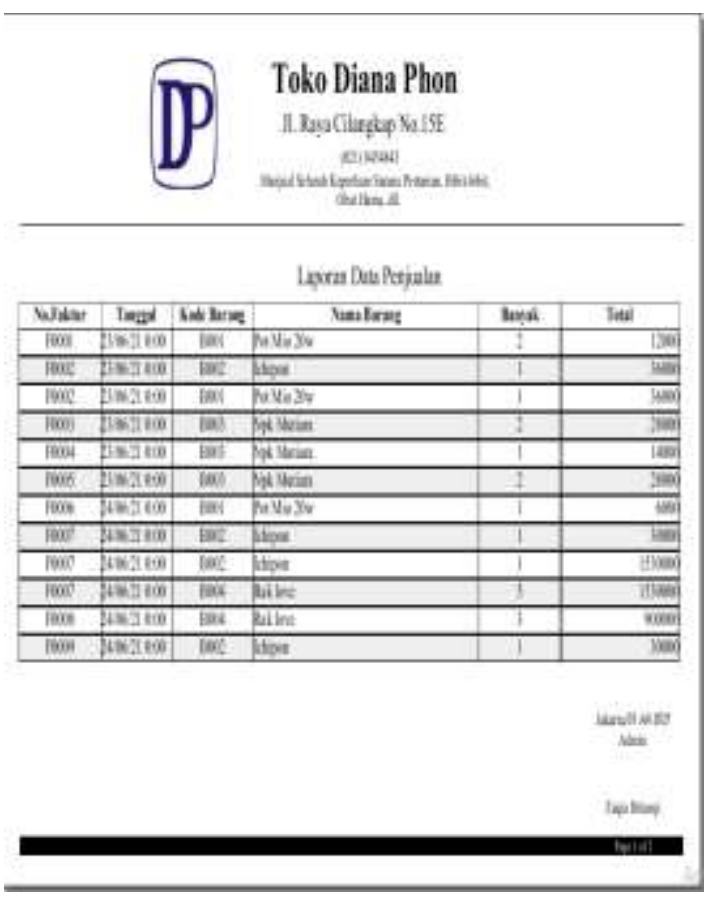

Gambar 10. Tampilan Laporan Penjualan

Tampilan diatas merupakan tampilan Form laporan penjualan dari menu data transaksi penjualan yang akan dijadikan laporan.

\section{SIMPULAN DAN SARAN}

Berdasarkan penelitian yang sudah dicoba penulis mengenai perancangan sistem informasi penjualan pada Toko Diana Phon
Jakarta, dapat diambil kesimpulan bahwa merancang sistem informasi transaksi penjualan produk pertanian yang meliputi beberapa proses transaksi antara lain proses mengolah data barang, customer, supplier, barang masuk, dan faktur penjualan. Mempermudah administrasi dalam memberikan laporan-laporan penjualan untuk meminimalisir kesalahan serta memberikan data dengan akurat dan cepat. Dengan adanya Sistem Informasi Transaksi Penjualan, maka saat ini pengolahan data penjualan sudah terkomputerisasi secara otomatis, sehingga dapat meningkatkan kinerja karyawan di dalam perusahaan.

Berdasarkan hasil evaluasi terhadap sistem informasi yang penulis bangun terdapat beberapa saran untuk pengembangan diantaranya adalah peneliti selanjutnya diharapkan lebih banyak lagi sumber dan referensi yang bisa dikaitkan dengan sistem informasi penjualan untuk hasil penelitian lebih baik dan lebih lengkap.

Pembuatan program ini masih dapat dikembangkan lagi seiring dengan berkembang spesifikasi kebutuhan pengguna, terutama dalam hal tampilan ada baiknya dibuat tampilan yang lebih menarik dan dikembangkan lebih lanjut. Program sistem informasi yang telah dibangun hanya dapat menentukan biaya paling ekonomis dari pemesanan yang bersifat normal, kedepannya bisa dikembangkan apabila ada pemesanan dengan rabat atau yang memberikan diskon pada jumlah pembelian tertentu.

\section{DAFTAR PUSTAKA}

Andi Taufik, Ermawati. (2013). "Sistem Informasi Koperasi Desa Berbasis Web Pada Desa Siduarjo." IJNS-Indonesian Journal on Networking and Security 2(3):4.

Astuti, Puspita Dwi. (2013). "Sistem Informasi Penjualan Obat Pada Apotek Jati Farma Arjosari." Indonesian Jurnal on Computer Science - Speed (IJCSS) 16 FTI UNSA Vol 10 No 1 - Mei 2013 Ijcss.Unsa.Ac.Id 10(1):142-47. doi: http://dx.doi.org/10.3112/speed.v3i4.12 17.

Darmawan, K.N. Fauzi, D. (2013). Sistem Informasi Manajemen. Bandung: PT. 
Remaja Rosdakarya.

Furqon, A. (2013). Perancangan Aplikasi Sistem Informasi Penjualan Berbasis Microsoft Access 2007 Pada Toko Syafa Collections, Laporan Akhir Politeknik Negeri Sriwijaya. Palembang: Politeknik Negeri Sriwijaya.

Haryanto, B. (2011). Esensi-Esensi Bahasa Pemrograman Java. Yogyakarta: Andi Offset.

Nugroho, B. (2013). Dasar Pemrograman Web PHP - MySQL Dengan Dreamweaver. Yogyakarta: Gava Media.

Rosa, A. Shalahuddin, M. (2015). Rekayasa Perangkat Lunak Terstruktur Dan
Berorientasi Objek. Bandung: Informatika Bandung.

Soetam, R. (2011). Konsep Dasar Rekayasa Perangkat Lunak. Jakarta: PT.Prestasi Pustakaraya.

Sugiyono. (2015). Metode Penelitian Kombinasi (Mix Methods). Bandung: Alfabeta.

Susanto, A. (2013). Sistem Informasi Akuntansi. Struktur Pengendalian Resiko-Pengembangan. Bandung: Lingga Jaya.

Westriningsih. (2012). Panduan Aplikatif \& Solusi (PAS) Membangun Aplikasi Bisnis Dengan Netbeans 7. Yogyakarta: Andi Offset. 